\title{
International transitional administrations and the politics of authority building
}

Article

Accepted Version

Zaum, D. (2017) International transitional administrations and the politics of authority building. Journal of Intervention and Statebuilding, 11 (4). pp. 409-428. ISSN 1750-2985 doi: https://doi.org/10.1080/17502977.2017.1385237 Available at https://centaur.reading.ac.uk/61773/

It is advisable to refer to the publisher's version if you intend to cite from the work. See Guidance on citing.

To link to this article DOI: http://dx.doi.org/10.1080/17502977.2017.1385237

Publisher: Taylor and Francis

All outputs in CentAUR are protected by Intellectual Property Rights law, including copyright law. Copyright and IPR is retained by the creators or other copyright holders. Terms and conditions for use of this material are defined in the End User Agreement.

\section{www.reading.ac.uk/centaur}

\section{CentAUR}

Central Archive at the University of Reading

Reading's research outputs online 


\title{
International Transitional Administrations and the Politics of Authority Building
}

\author{
Dominik Zaum, University of Reading \\ Draft only - do not quote \\ 16 February 2015
}

\section{Introduction}

Statebuilding discourses - and the concomitant discourses over state failure or state fragility - have shifted substantially over the last decade, both among scholars and donors. While early work focussed largely on questions of state capacity - e.g. territorial control or the provision of basic public goods and services ${ }^{1}$ - or more controversially on regime type (e.g. lack of democracy) $)^{2}$, and on ways in which state capacity could be strengthened or regimes transformed, recently there has been a greater recognition of the importance of political authority. The building of legitimate political authority has been identified as a central aspect of statebuilding efforts both by academics, ${ }^{3}$ and by donors such as DFID, the OECD/DAC and the World Bank. ${ }^{4}$

This shift in thinking about state fragility and statebuilding (to the extent that it is reflected in statebuilding practice $)^{5}$ is substantial, as it implicitly recognises the deeply political nature of statebuilding. While there is undoubtedly an important political dimension to building capacity (as strengthening the capacity of particular actors and organisations can shift the

\footnotetext{
${ }^{1}$ Robert Rotberg, for example, argues that failed states "are consumed by internal violence and cease delivering positive political goods to their inhabitants." Robert Rotberg, "The Failure and Collapse of Nation-States: Breakdown, Prevention, and Repair", in Robert Rotberg (ed.), When States Fail: Causes and Consequences (Princeton: Princeton University Press, 2004), p.1.

2 James Dobbins and his collaborators, for example, define "nation-building" as the use of armed force in the aftermath of conflict to promote democracy". James Dobbins, Seth Jones, Keith Crane, Andrew Rathmell, Brett Steele, Richard Teltschick, and Anga Timilsina, The UN's role in Nation-Building: From the Congo to Iraq (Santa Monica: Rand, 2005), p.2.

${ }^{3}$ See for example Roland Paris and Timothy Sisk (eds.), The Dilemmas of Statebuilding: Confronting the Contradictions of Postwar Peace Operations (Abingdon: Routledge, 2009); Dominik Zaum, The Sovereignty Paradox: The Norms and Politics of International Statebuilding (Oxford: Oxford University Press, 2007).

${ }^{4}$ Department for International Development (DFID), Building Peaceful States and Societies: A DFID Practice Paper (London: DFID, 2009), OECD/DAC, The State's Legitimacy in Fragile Situations (Paris: OECD, 2011); World Bank, World Development Report 2011: Conflict, Security, and Development (Washington D.C.: World Bank, 2011).

${ }^{5}$ For a critique of the gap between such rhetoric and actual practice of the IFIs in fragile states, see Susan Woodward, "The IFIs and post-conflict political economy", in Mats Berdal and Dominik Zaum (eds.), Political Economy of Statebuilding: Power after Peace (Abingdon: Routledge, 2012), 140-57. See also Independent Evaluation Group, World Bank Group Assistance to Low Income Fragile and Conflict-Affected States: An Independent Evaluation, Washington D.C.: World Bank Group, December 2013, which suggests that despite the growing use of conflict analysis by the World Bank, its programmes in fragile states continue to make little use of it, especially in their implementation ( pp.17-9).
} 
underlying balances of power in a war-torn society), ${ }^{6}$ it is largely construed as a technical activity involving the design and strengthening of institutions and processes, of training, and of resources. ${ }^{7}$ In contrast to capacity to develop and implement public policy and deliver public goods, war-torn states rarely lack authority - or to be more precise, they do not lack actors making authority claims. These claims, however, are often competing and mutually exclusive, and importantly they are often not widely recognised (if at all). Building authority, therefore, means that external statebuilding actors have to make a choice between different actors and organisations, recognising the authority claims of some and withhold recognition from others, and seek ways to strengthen their ability to justify their authority claims vis-à-vis domestic and international audiences. Through authority building practices, external actors directly become part of the political competition and dynamics of war-affected societies.

Authority building in the context of international statebuilding interventions, however, not only relates to local political authority. Given that almost all statebuilding efforts have substantial transformative ambitions for the scope and character of the state and of statesociety relationships, they themselves make authority claims with regard to local elites and the wider population. In some cases - military occupations, complex peace operations, and in particular in international transitional administrations - external actors exercise limited or comprehensive state functions: executive, legislative, as well as judicial. ${ }^{8}$ Any analysis of authority building in the context of statebuilding interventions therefore needs to take account of the complex relationship between the building of international and of local authority in these environments.

This article critically examines authority-building practices in the context of statebuilding through the lens of one particular form of external statebuilding interventions: international

\footnotetext{
${ }^{6}$ A recent study of the Asia Foundation, for example, highlights how donor aid to strengthen government capacity can fuel sub-national conflict. See Thomas Parks, Nat Colletta, and Ben Oppenheim, The Contested Corners of Asia: Subnational Conflict and International Development Assistance (Bangkok: The Asia Foundation, 2013).

${ }^{7}$ As Ken Menhkaus has argued, "By reducing state failure to a matter of low capacity, this view lends itself to technical solutions ... More funding, better trained civil servants, a more professionalised and equipped police force, and a healthy dose of democratisation (where not politically inconvenient) have been the main elements of state-building strategies." Ken Menkhaus, "State failure and ungoverned space", in Mats Berdal and Achim Wennmann (eds), Ending Wars, Consolidating Peace: Economic Perspectives (Abingdon: Routledge for the IISS, 2010), p.176.

${ }^{8}$ For an overview, see Richard Caplan, International Governance of War-Torn Territories (Oxford: Oxford University Press. 2005); Simon Chesterman, You, the People: The United Nations, Transitional Administration, and State-Building (Oxford: Oxford University Press, 2004); Ralph Wilde, International Territorial Administration: How Trusteeship and the Civilizing Mission Never Went Away (Oxford: Oxford University Press, 2008); Dominik Zaum, The Sovereignty Paradox: The Norms and Politics of International Statebuilding (Oxford: Oxford University Press, 2007).
} 
transitional administrations (ITAs), which are established by international organisations (mainly the UN) to exercise governmental functions over a territory, and in some cases to engage in the establishment or reform of political, administrative, and economic institutions. ${ }^{9}$ ITAs are interesting for this analysis both because their formal-legal mandates are arguably the most intrusive of all types of multilateral interventions, with international (normally UNmandated) actors exercising different degrees of executive, legislative, and judicial authority, and because in their post-cold war incarnation they have frequently had far-reaching statebuilding (and authority building) responsibilities. The analysis below will draw in particular on one ITA, the UN Interim Administration Mission in Kosovo (UNMIK).

The objective of this article, however, is not the detailed examination of particular authority building practices, or to evaluate the practices of a particular international administration. Instead, it aims to critically evaluate authority building as a framework for understanding the practices of statebuilding operations, and to understand the complexities of political authority in statebuilding environments, and their implications for both the pursuit and the analysis of authority building.

The discussion of authority building by ITAs will proceed in three steps. The next section will briefly outline the concept of political authority, in particular in the context of fragile and conflict-affected states and of international administrations, and discuss relevant methodological issues. Building on this, section two then examines three distinct aspects of authority building by ITAs: claiming and justifying their own authority; recognising and validating the authority claims of local actors and organisations; and strengthening the capacity of local actors to justify their authority claims. The final section concludes the paper with some reflections on political authority and authority building that arise from the discussion in the previous sections.

\footnotetext{
9 For a detailed discussion of ITAs and their mandates, see Carsten Stahn, The Law and Practice of International Territorial Administration (Cambridge: Cambridge University Press, 2008); Wilde, International Territorial Administration. As Steven Ratner has argued, the distinction between International Territorial Administration (authorised and managed by international organisations) and military occupation by a single state or group of states is increasingly blurred as they are governed by common legal frameworks, such as international humanitarian law, international human rights law, and the authorisation or endorsement of authority by international organisations. See Steven R. Ratner, "Foreign Occupation and International Territorial Administration: The Challenge of Convergence", European Journal of International Law, 16/4, pp.695-714.
} 


\section{Conceptualizing and Studying the Authority and International Transitional Administrations}

Before embarking on an analysis of authority building, it is important to be clear on what this paper means by authority, and how it will be studied. This section sets out the basic conceptual and methodological framework for this analysis.

\section{Conceptualising the Authority of International Administrations}

Following Bruce Cronin and Ian Hurd, authority is defined as "a relation among actors within a hierarchy in which one group is recognized as having both the right and the competence to take binding decisions for the rest of the community." 10 Authority, therefore, is a form of power, but power resting on recognition based on legitimacy, rather than coercion or material incentives. In John Ruggie's memorable phrase, authority is "the fusion of power with legitimate social purpose." 11

Authority has therefore several characteristics that help with identifying and evaluating practices of authority building by ITAs. The first is that authority is a social concept that needs to be both claimed and recognized. This raises the questions of who makes authority claims, at what audiences they are directed; and also whose recognition matters, and why? Authority claims can be made not only by local elites, but also by ITAs (who have been given, after all, formal authority in their international mandates). Recognition by different actors is likely to matter for different reasons: recognition from different local elites should reduce the risk of challenges to authority claims, recognition by ordinary citizens should increase compliance, while recognition from external actors might increase material or diplomatic support, for example. From this social character of authority, two authority building practices of international transitional administrations can therefore be identified: first, they can make claims about their own authority, and second, they can recognise the authority claims of selected local actors.

Second, authority needs to be legitimated - its claim or recognition needs to justified in terms of moral or other socially embedded beliefs. This raises the question of what the wider norms are within which authority claims in conflict-affected societies are embedded, and with reference to which authority is claimed or recognised. In particular if authority claims are made towards different audiences - both local and international - these norms might differ

\footnotetext{
${ }^{10}$ Bruce Cronin and Ian Hurd, "Introduction", in Bruce Cronin and Ian Hurd (eds.), The UN Security Council and the Politics of International Authority (London: Routledge, 2008), p.6

${ }^{11}$ John Gerard Ruggie, Constructing the World Polity: Essays in International Institutionalization (London: Routledge, 1998), p.64.
} 
and even conflict. Furthermore, in conflict-affected environments authority is inherently contested: in the absence of a clear victory by one party, there are likely to be a range of actors claiming political authority. These claims are often made on mutually exclusive grounds, with the main audience a particular ethnic group, for example, rather than society as a whole. In such environments, authority is claimed and recognised with regard to a range of different normative frameworks. These can include an emphasis on formal-legal processes and structures (e.g. elections, or formal constitutional provisions); the invocation of exclusive representational claims on the basis of ethnicity or religion; appeals to traditional understandings and structures of authority, such as tribal structures; or the salience of informal war-time structures and organisations. In addition, many of these actors will have some capacity to enforce their decisions (within certain territorial or community bounds), or at least have the capacity to effectively resist the enforcement of decisions taken by others. Both this normative pluralism, and the capacity of a range of actors to enforce at least some of their authority claims strongly affects the kind of practices of authority building that are feasible, and the kind of authority the development of which external actors can support. For international transitional administrations, both the claiming and recognition of authority therefore requires careful navigation of different normative landscapes.

Third, authority requires competence, the capacity to make and to some extent enforce decisions, if necessary through coercion. David Lake has argued for the importance for an authority to have some capacity for coercion, "to sustain authority in the face of incentives to flout the rules designed to constrain behaviour". ${ }^{12}$ Competence, however, is not only important for the prevention of rule-breaking and ensuring the fair application of rules to those subject to an authority, but also to provide the wider public goods for which other actors voluntarily submit to authority. Authority building can therefore not be separated from building the capacity to make and enforce decisions.

\section{Studying the Authority-Building Practices of International Administrations}

The examination of authority building practices of ITAs raises three important methodological issues: first, how to identify relevant practices; second, how to study them; and third, the justification of cases.

\footnotetext{
12 David Lake, "Escape from the State of Nature: Authority and Hierarchy in World Politics", International Security 32, no.1 (2007), 52.
} 
Following Barry Barnes, practices are defines as "socially recognised forms of activity, done on the basis of what members learn from each other, and capable of being done well or badly, correctly or incorrectly." 13 Such practices can involve the production of documents (such as constitutions or resolutions), the spoken word (such as public speeches or editorials), and actions (such as prosecutions, arrests, dismissals, or appointments). This paper derives broad categories of relevant practices from the earlier conceptual discussion of authority, in particular from its social character and the associated need for it to be both claimed and recognised. If we can break down authority building practices into those related to claiming and recognising authority, and further break each down into ITA practices aimed at themselves or at local actors (mainly elites), we can identify three main types of practices of ITAs that can be said to contribute to building authority: These are the claiming and justifying of their own authority, the recognition of the authority claims of selected local actors, and the strengthening of the capacity of selected local actors to support their authority claims. A fourth practice - an ITA's recognition of its own authority claims - could be described as self-legitimation, as an effort to affirm and strengthen an ITA's identity vis-a-vis its own staff in particular. ${ }^{14}$ This, however, is beyond the scope of the analysis here because of the specific statebulding focus of this paper. The different categories of practices are summarised in Figure 1.

\begin{tabular}{|c|c|c|}
\hline \multicolumn{2}{|c|}{ Figure 1: Summary of ITA Authority Building Practices } \\
\hline \multirow{3}{*}{ ITAs } & $\begin{array}{c}\text { Practices that assert and justify } \\
\text { the right of an ITA to exercise } \\
\text { political power }\end{array}$ & $\begin{array}{c}\text { Self-Legitimation - individual } \\
\text { staff members of an ITA } \\
\text { recognising the claims to political } \\
\text { authority made by their } \\
\text { organisation }\end{array}$ \\
\hline $\begin{array}{c}\text { Local } \\
\text { Elites }\end{array}$ & $\begin{array}{c}\text { Practices that enable local elites } \\
\text { to assert and justify their right to } \\
\text { exercise political power }\end{array}$ & $\begin{array}{c}\text { Recognition of the claims to } \\
\text { political authority made by local } \\
\text { elites }\end{array}$ \\
\hline
\end{tabular}

The second methodological issue concerns the ways in which the practices identified can be studied and interpreted. In line with most international practice theory research, ${ }^{15}$ the approach chosen is qualitative, using data from participant observation, complemented with

\footnotetext{
${ }^{13}$ Barry Barnes, "Practices as Collective Action", in Theodore R. Schatzki, Karin Knorr Cetina, and Eike von Savigny (eds.), The Practice Turn in Contemporary Theory (London: Routledge, 2001), 19.

${ }^{14}$ Self-legitimation has spurned a growing literature in IR in recent years, including ADD

${ }^{15}$ For an overview, see Christian Bueger and Frank Gadinger, International Practice Theory: New Perspectives (Basingstoke: Palgrave Macmillan, 2014).
} 
textual analysis of speeches, visual images like graffiti, and secondary literature to identify and discuss different practices. As the main objective of this paper is to develop a conceptual framework to understand the authority building practices of international administrations, the purpose of the discussion of actual practices is merely to evaluate the utility of the proposed analytical framework, not to assess changes in ITA practice or to systematically evaluate the impact of particular practices. The empirical discussion of different practices is therefore illustrative and exploratory, rather than comprehensive and evaluative.

The third methodological issue concerns the selection of cases. As discussed earlier, international administrations are a useful lens to examine authority building because of the comprehensive authority they themselves claim (and have been formally endowed with by international organisations), and because of their statebuilding mandates, especially in the post-cold war era. The overall universe of cases of ITAs, however, is small: between 1919 and 1999, only 12 ITAs were established. ${ }^{16}$ These include the three territorial administrations established by the League of Nations (in Danzig, the Saar Basin, and in Leticia); cold-war ITAs established by the UN during the 1960s to address specific decolonisation challenges (in West New Guinea and the Congo), and post-cold war international administrations in Cambodia, the Balkans (Bosnia, Kosovo, Eastern Slavonia, and the cities of Mostar and Brçko) and East Timor. Notably, none of the League- and cold-war international territorial administrations had a statebuilding mandate.

To examine their authority building practices, this article will therefore draw on the seven post-cold war international administrations, but focus in particular on the UN Interim Administration Mission in Kosovo's (UNMIK) efforts. This particular case is chosen because the longevity of the mission (functioning as an ITA for nine years from 1999 - 2008), and the comprehensive scope of the mandate provide a rich seam of authority building practices to examine, including through participant observation. ${ }^{17}$

\section{Authority-building by International Transitional Administrations}

\section{Claiming and justifying their own authority}

The seven international transitional administrations since the end of the cold war have claimed varying degrees of authority. All of them have claimed (mostly temporary)

\footnotetext{
${ }^{16}$ For a full list of international administrations and their mandates, see Dominik Zaum, "Exit and International Administrations", in Richard Caplan (ed.), Exit Strategies and Statebuilding (New York: Oxford University Press, 2012), Table 8.1 (pp.140-3).

17 This paper draws on regular fieldwork conducted in Kosovo between 2003 and 2011, working both with UNMIK and with local research organisations.
} 
administrative authority, either sectoral - e.g. the UN Transitional Administration in Cambodia (UNTAC), which claimed authority over key government departments to improve the chances of free and fair elections ${ }^{18}$ - or comprehensive, as UNMIK in Kosovo or the UN Transitional Administration in East Timor (UNTAET). ${ }^{19}$ The post-cold war administrations have also claimed varying degrees of transformative authority. This has ranged from as little as organising elections (UNTAC) and transforming sub-state level institutions (the UN Transitional Administration for Eastern Slavonia, Baranja, and West Sirmium, UNTAES) to comprehensive efforts at reconstructing the state and state-society relationships (as the Office of the High Representative (OHR) in Bosnia, UNMIK, and UNTAET). ${ }^{20}$ International transitional administrations have justified their authority primarily in formal-legal terms, with reference to their UN Security Council mandates in the case of all UN-authorised operations, ${ }^{21}$ or to formal peace agreements like the Dayton Agreement for Bosnia and Herzegovina in the case of the OHR. ${ }^{22}$ Thus, delegation from a higher authority - the UN Security Council and its Chapter VII powers - and consent from the conflict parties expressed in a peace agreement have been at the heart of international administrations' authority claims. $^{23}$

Importantly, though, the authority claims made by ITAs themselves have been inherently limited in both time and scope. With regard to the former, almost all international administrations have an explicitly transitional character with either fixed end dates (often culminating in elections, as in Cambodia) or governance benchmarks that at least formally structure the transition process to local rule, as in Kosovo, or East Timor. In the post-cold war period, the only exception to this has been the supervisory regime for the small Bosnian city of Brcko (which in practice, however, ended in 2012, ahead of the closure of the OHR). ${ }^{24}$ While some international administrations have lasted over a decade (e.g. the OHR in Bosnia,

\footnotetext{
${ }^{18}$ SC Res. 745 of 28 February 1992. See also Michael Doyle, UN Peacekeeping in Cambodia: UNTAC's Civil Mandate (Boulder. Co.: Lynne Rienner, 1995).

19 SC Res. 1244 of 10 June 1999 and SC Res. 1272 of 25 October 1999. See also Dominik Zaum, "The Authority of International Administrations in International Society", Review of International Studies 32/3, (2006), 455-73.

${ }^{20}$ Ibid.

${ }^{21}$ e.g. SC Res. 1244; SC Res. 1272.

${ }^{22}$ Peace Implementation Conference 1997 - Bosnia and Herzegovina 1998: Self-sustaining Structures, Bonn, 910 December 1997, Art.XI.2.

${ }^{23}$ Zaum, "The Authority of International Administrations in International Society".

${ }^{24}$ Alex Jeffrey, "Building State Capacity in Post-Conflict Bosnia and Herzegovina: The case of Brčko District", Political Geography, Vol.25 (2006), pp.203-227. The only other exception wikthin the whole universe of ITA cases was the League of Nations High Commission at Danzig, which, however, ended with the German occupation of Poland in 1939. See John Kurt Bleimaier, "The Legal Status of the Free City of Danzig 1920 1939: Lessons to be Derived from the Experiences of a Non-State Entity in the International Community", Hague Yearbook of International Law, (1989).
} 
or UNMIK and its successor missions in Kosovo), most have ended within several years, not least because the international political will to sustain them at substantial expense is arguably limited, especially in the absence of immediate wider security concerns. With regard to the latter, ITA authority claims have been circumscribed by their mandates' provision to build and transition to local authority. Six of the seven post-cold war international transitional administrations had explicit statebuilding mandates, and did foresee the gradual transition of authority from international to local actors. ${ }^{25}$

How have ITAs justified their authority claims? In their official statements, decisions, and regulations, ITAs have regularly emphasised both their formal legal mandate and their authority deriving from UN Security Council resolutions in particular. In Kosovo, for example, the authority of UNMIK was primarily derived from its Chapter VII mandate outlined in Security Council Resolution $1244 .{ }^{26}$ The first regulation issued by UNMIK in July 1999, aptly titled "On the Authority of the International Administration in Kosovo", explicitly invoked Resolution 1244 and Chapter VII of the UN Charter when vesting all executive and legislative authority with respect to Kosovo in the Special Representative of the UN Secretary General in Kosovo, the head of the Mission. In addition, though, ITAs have frequently invoked the weakness of local government institutions, the poor quality of local governance, and the risk of conflict recurrence in the absence of international authority, thus justifying their authority claims with reference to limited local governance capacity. ${ }^{27}$

Exemplary of this was the so-called "standards before status" policy in Kosovo, that was originally devised in 2002 by the then head of UNMIK, Michael Steiner. ${ }^{28}$ It outlined eight governance standards including, inter alia, functioning democratic institutions, the rule of law, freedom of movement, the sustainable return of refugees, and the establishment of a market economy. By the end of 2003 the resolution of Kosovo's status, and with it the full transition of authority from international to local actors, was formally made conditional upon

\footnotetext{
${ }^{25}$ Only UNTAC in Cambodia had no explicit statebulding mandate.

${ }^{26}$ SC Res. 1244 of 10 June 1999.

${ }^{27}$ In the case of Kosovo, these were complemented with references to the need to protect minorities against violence, and the unresolved legal and political status of Kosovo (and the potential for future conflict residing in this).

${ }^{28}$ The standards were first publicly announced in a speech by Michael Steiner at the UN Security Council on April 24, 2002. See UN Doc. S/PV.4518 of 22 April 2002, pp. 2-4.
} 
the fulfilment of these standards. ${ }^{29}$ UNMIK's claim to the continued exercise of political authority thus rested on the perceived weakness of local political institutions.

Justifying their authority claims with reference to the weakness of alternative formal authority structures, however, arguably requires some evidence that international administrations provide more effective governance than local actors could, or effectively reduce the risk of further organised violence in the aftermath of conflict. Given the substantial physical destruction, the exclusion of Albanians from public employment since the early 1990s, and the displacement of Serb officials; and the ethnic revenge violence in the immediate aftermath of the Kosovo war, and continued low-level violence against and exclusion of ethnic minorities for some time later, ${ }^{30}$ it is highly plausible that the international military and police presence contained violence and prevented conflict recurrence, and that the civilian international administration could provide resources and expertise to both provide governance and build and strengthen institutions. However, it is also important to note how the limitations of UNMIK's capacity undermined its authority claims. Most importantly, for over half a year, the presence of UNMIK outside the capital was severely constrained. By late 1999, UNMIK was present in only 18 of the territory's 29 municipalities, and it chaired the municipal board (and thus effectively claimed authority) in only nine of them. ${ }^{31}$ Throughout the territory, its authority was challenged by a parallel administration declared by the UCK, which claimed administrative authority and which issued official documents and licenses in municipalities, "privatised" enterprises and land, and whose only partially demobilised fighters provided their own form of security and justice. ${ }^{32}$ To effectively extend its formal authority and to contain these challenges, UNMIK had to co-opt these groups into the formal governance structures - which de facto recognised some of their authority claims, started a process of complex negotiations over and sharing of power between local elites and the international administration.

Such an outcome, as Tim Sisk and Christoph Zuercher have argued, is far from unique to Kosovo: in most statebuilding operations, international actors enter an informal "statebuilders' compact" with local elites that minimises violence but also constrains the transformative ambitions of international actors and entrenches the authority of war-time

\footnotetext{
${ }^{29}$ The proposal remained silent about the nature of the final status, yet it was implicit that this would be some form of independence. See Iain King and Whit Mason, Peace at any Price: How the World Failed Kosovo, (London: Hurst, 2006) pp. 174-5.

${ }^{30}$ See for example Tim Judah, Kosovo: War and Revenge (New Haven: Yale University Press, 2000).

${ }^{31}$ Zaum, Sovereignty Paradox, 135.

${ }^{32}$ International Crisis Group, Waiting for UNMIK_Local Administration in Kosovo (Pristina: ICG, 1999)
} 
elites. $^{33}$ Such implicit compacts, rooted in the limited coercive capacity of international administrations, clearly circumscribe their ability to claim authority. Such "statebuilders' compacts" suggest that while ITAs with their often comprehensive formal authority might on paper appear to be at the pinnacle of a hierarchical authority structure, in reality are part of a more complex reality of overlapping and interwoven authorities, where they have to co-opt local elites, leading to a complex reality of continuous contestation and negotiation over authority between international transitional administrations and local elites.

Authority claims, however, not only rest on capacity or competence, but also on shared ideas about the ends to which it is exercised. ${ }^{34}$ When the exercise of authority is seen as contributing to these shared ends, it is more likely to be recognised and considered legitimate than in situations where it is seen as detracting from it. The ability of ITAs to tap into local normative frameworks, however, is clearly constrained by their international character and anchoring in well-established liberal international normative frameworks. It would be inconceivable, for example, that a UN authorised international administration mission would not promote international human rights norms, for example, or explicitly engage upon the establishment of exclusive and authoritarian regimes. It can lead to conflict between ITAs and local elites, for example over the access of minorities to political office (as in Bosnia), ${ }^{35}$ or over the role of informal traditional justice mechanisms (as in Timor Leste) ${ }^{36}$ Similarly, if the outcome of a period of international administration remains contested - e.g. if there is no agreement on the kind of state the development of which its statebuilding policies are supposed to support or, worse, if there is no agreement on whether it should be a state at all its authority is likely to be challenged.

In Kosovo, the lack of agreement on Kosovo's future status, and the provisions in Resolution 1244 that gave UNMIK the mandate to work towards the resolution of the status question, but not the power to take any decision on it, inherently undermined its ability to build its authority. The key objective of Kosovo's political elite, independence, was not within UNMIK's power to deliver, and its ability to maintain its authority consequently declined

\footnotetext{
${ }^{33}$ Michael Barnett, and Christoph Zürcher, "The peacebuilder's contract: how external statebuilding reinforces weak statehood", in Roland Paris and Timothy Sisk (eds), The Dilemmas of State building: Confronting the Contradictions of Post-War Peace Operations (Abingdon: Routledge, 2009), pp. 23-52.

${ }^{34}$ Fritz Scharpf, Governing in Europe: Democratic and Effective? (Oxford: Oxford University Press, 1999).

35 Anna Morawiec Mansfield, "Ethnic but equal: the quest for a new democratic order in Bosnia and Herzegovina." Columbia Law Review 103/8 (2003), 2052-93.

${ }^{36}$ Tanja Hohe and Rod Nixon, 'Reconciling Justice: “Traditional” Law and State Judiciary in East Timor', Draft Report prepared for the US Institute for Peace, January 2003,
} 
over time. While there is no obvious way to measure such a decline, it is reflected in the levels of satisfaction that Kosovars express with regard to UNMIK, which according to USAID and UNDP survey data declined from over $60 \%$ in 2002 to just about $20 \%$ in the aftermath of the violent riots in March 2004, and remain very low as UNMIK was increasingly seen as an obstacle rather than a contributor to independence. In contrast the NATO-led peacekeeping force, KFOR, which most Albanians credit with "liberating" them from Serb rule (and whose authority does not rest on delivering independence, economic development or better governance, but merely on providing a modicum of security), maintained high support throughout that period. ${ }^{37}$

Authority claims of international administrations also need to address diverse audiences, both international and domestic. The key audience of authority claims, however, are local elites (and to a lesser extent the wider population), as they are the actors that could make competing claims and directly challenge international transitional administrations. Building their own authority therefore means for ITAs that they need to contain competing claims and challenges from local elites. International administrations need to justify their authority also vis-à-vis other international actors, especially powerful donors, to sustain both their political and financial support. In Kosovo, some governments of the so-called "quint" group of states (France, Germany, Italy, the UK, and the US) could use their close links and their leverage over local elites to reign them in and thereby support UNMIK's authority claims. Similarly, when such powerful external actors no longer recognise the authority of an international transitional administration, its ability to gain recognition and compliance from local actors declines dramatically. ${ }^{38}$ When divisions in the UN Security Council prevented the closure of UNMIK in the aftermath of the Kosovar declaration of independence, the effective withdrawal of recognition from the US and major European states of UNMIK's authority, as reflected for example in the decision of EU police contributors to withdraw their contingents from UNMIK and instead contribute to the EULEX rule of law mission in Kosovo, substantially limited the ability of UNMIK to claim authority vis-à-vis local actors and institutions, and their willingness to recognise them.

\section{Recognising the authority claims of selected local actors}

Compared to the authority of international administrations themselves, the authority of local actors that ITAs seek to build and shape is arguably even more important for the longer-term

\footnotetext{
${ }^{37}$ USAID/UNDP, Kosovo Early Warning Report \#17, Pristina, April-June 2007, p.15.

${ }^{38}$ Ben Crampton, "Kosovo", in Richard Caplan (ed.), Exit Strategies and Statebuilding (Oxford: Oxford University Press, 2012), 159-76.
} 
outocmes of statebuilding and peacebuilding processes, and is a central part of the statebuilding mandates that many international administrations have been endowed with. While statebuilding efforts are often framed as being focussed on establishing and strengthening impersonal rules and organizations that regulate access to political power, and provide public goods and services, ${ }^{39}$ they also (directly or indirectly) impact on local political actors and their claims to authority. The two forms of local authority building examined here - recognition of authority claims, and strengthening the capacity or competence of local actors claiming authority - are therefore inherently political: they involve international transitional administrations in local political dynamics, they require them to take sides, and give them an important role in what David Eason has termed the "authoritative allocation of values". 40

As a social concept, authority not only needs to be claimed, but also recognized. International administrations are an important audience for the authority claims of local actors, both because of their formal statebuilding mandates, and because they can represent the wider international community. Their recognition thus represents or at least facilitates a wider international endorsement of authority claims.

ITAs can recognise the authority claims of local actors in different ways, and with different possible consequences. On the one end, recognition actions include official meetings or endorsements that identify local actors as an interlocutor and endow them with a certain status. At the other end, they include the formal inclusion of local actors in advisory bodies or the appointment to formal positions in transitional governments. The latter are arguably particularly important, because they not only reinforce informal authority claims with the formal authority of government institutions, but also gives those actors access to rents and material resources and to institutional prestige, and gives them public visibility that can help to further advance their authority claims.

In most cases, the choice as to whose claims to recognise reflects the "reality on the ground": actors exercise de facto control over territory, or can demonstrably mobilise substantial groups, either in support or against the international presence. In East Timor, for example, the UN Transitional Administration (UNTAET) quickly established a National Consultative Council (NCC) with a broad range of Timorese leaders, but the Head of the Mission was

\footnotetext{
${ }^{39}$ Roland Paris, At War's End: Building Peace After Civil Conflict (New York: Cambridge University Press, 2004); Timothy Sisk, Statebuilding (Cambridge: Polity, 2013).

${ }^{40}$ David Easton, The Political System: An Inquiry into the State of Political Science (New York: Alfred A. Knopf, 1953).
} 
widely seen as relying almost exclusively on Xanana Gusmao, the charismatic leader of the resistance movement $\mathrm{CNRT}^{41}$ - who after independence served first as president and later as prime minister of East Timor. In Kosovo, both the parallel administration of the "Republic of Kosova", led by Ibrahim Rugova, and the UCK-led "Provisional Government of Kosova" demanded to be recognised as the formal government from UNMIK in the immediate postwar months in 1999, when UNMIK's presence outside the capital was very limited, and its control was tenuous. ${ }^{42}$ UNMIK increased the local participation in formal political and administrative structures much earlier than intended and co-opted the leadership of both groups into its key institutions, and effectively recognised the authority claims by different local political leaders, in exchange for the dismantling of parallel institutions that challenged its own authority. ${ }^{43}$ The example highlights not only how recognition of local authority claims by international administrations has been responsive to the actual realities of power on the ground, but also how the authority of international administrations themselves is inherently contested and negotiated by local authorities, and how intertwined local and international authority can be under conditions of international administration. Importantly, it also highlights how recognition of authority claims can strengthen the affected actors, by enhancing their status and endowing them with resources. ${ }^{44}$

The other side of the coin of recognition of authority, of course, are efforts to de-legitimate the authority claims of local actors through exclusion from formal consultations and institutions, through public declarations, or even through legal prosecution. In particular in Bosnia and Kosovo, the international administrations actively tried to de-legitimise the authority claims by different local actors - in particular those considered as "nationalist". In Bosnia, successive High Representatives used the so-called "Bonn Powers" to remove and ban from holding public office a range of politicians and officials who were considered as obstructing the implementation of the Dayton Peace Agreement. ${ }^{45}$ Between 1997 and 2005,

\footnotetext{
41 Jarat Chopra, 'The UN's Kingdom of East Timor', Survival, 42/3 (2000).

42 ICG, Waiting for UNMIK, 2-3.

${ }^{43}$ Marcus Brand, The Development of Kosovo Institutions and the Transition of Authority from UNMIK to Local Self-Government (Geneva, Switzerland: CASIN, 2003).

44 An additional example from Kosovo was the Coordination Centre for Kosovo and Metohija (CCK), a body established by the Serbian government without any formal relationship to the governmental institutions established by UNMIK in Kosovo, but an integral part of the informal governance and patronage structures in Serb-majority Northern municipalities in particular. While the CCK undermined the formal UNMIK-established institutions, it became the key Serb interlocutor for UNMIK and the wider international presence. See Dominik Zaum with Verena Knaus, "The political economy of statebuilding in Kosovo", in Mats Berdal and Dominik Zaum (eds.), Political Economy of Statebuilding: Power after Peace (Abingdon: Routledge, 2012), 240-1.

45 The "Bonn Powers" refer to the right of the High Representative to review, amend, and impose legislation, and to dismiss officials considered to be obstructing the implementation of the Dayton Peace Agreement. The
} 
the period of most active use of the Bonn Powers, over 180 officials and politicians were removed from office by the High Representative. ${ }^{46}$ In Kosovo, UNMIK did not remove politicians from office, but worked hard to exclude and ostracise the nationalist Vetvendosje movement that explicitly called for Kosovo's immediate independence and the departure of the international presence (except NATO). This included the arrest and prosecution of the movement's leader, Albin Kurti, for public order offences arising from a pro-independence demonstration in February 2007, where UNMIK policemen shot two protesters. The trial was widely criticised by human rights organisations and (behind closed doors) by the OSCE (which contributed to UNMIK at the time) for its procedural flaws. ${ }^{47}$ In neither the case of Bosnia and Kosovo is it obvious that the explicit efforts to de-legitimise local authority claims worked. In Bosnia, the OHR re-instated a substantial number of the politicians it had removed from office, and while the removal of prominent opponents of the international community's then favoured local candidate (Milorad Dodik) might have contributed to his electoral successes entrenchment of his party, he has been increasingly seen by the same internationals as the face of Serb nationalism in Bosnia, and as a challenge to the Dayton peace process. ${ }^{48}$ In Kosovo, the court case against Kurti was suspended by UNMIK when the Kosovo Bar Association refused to appoint a defence lawyer for him. When EULEX restarted the trial in 2010, two of the three charges were dropped, and while he was found guilty on one charge, he was released immediately in recognition of the time spent in arrest already. ${ }^{49}$ Vetvendosje continued to transform itself into a political party and compete successfully in national and local elections, winning the post of Mayor in Kosovo's capital Prishtina in November 2013, and becoming the third strongest party with over $12.5 \%$ of the votes in the 2014 parliamentary elections.

One of the wider conclusions that this discussion of practices of recognition of authority claims by international administrations suggests is that the value of this recognition inherently depends on their own authority - and that there might come a point where an

\footnotetext{
"Bonn Powers" were asserted by the High Representative and the Peace Implementation Council (PIC) at the PIC meeting in Bonn in 1997, on the basis of a wider interpretation of the Dayton Agreement's provision that the High Representative is the "the final authority in theatre regarding the interpretation of [the GFAP] on the civilian implementation of the peace settlement" See Zaum, Sovereignty Paradox, 83-4.

${ }^{46}$ Ibid. 93-4.

47 Amnesty International, Kosovo (Serbia): Albin Kurti - A Politically Motivated Prosecution, London, 10 December 2007.

${ }^{48}$ See for example the testimony of the Deputy High Representative, Raffi Gregorian, to the US Commission on Security and Cooperation in Europe, 8 November 2007. Available at http://csce.gov

49 EULEX, "Verdict in Albin Kurti Case", Press Release, Prishtina, 14 June 2010. Available at http://www.eulex-kosovo.eu/en/pressreleases/0067.php
} 
explicit endorsement by an ITA could become a liability for local actors claiming political authority. ITA recognition matters most for local actors early on in a state- and peacebuilding process, when local authority is fragile and contested, and recognition is seen as conferring the support and approval of the wider international community. For local actors, the obvious benefits from such recognition extend to the access to formal political institutions and to rents, which can support their ability to build a strong political base. Under several conditions, recognition by an international administration can be detrimental to the authority claims of local actors. In particular if an international administration is seen as not supporting key objectives of the local community (e.g. independence in Kosovo) and is seen as an obstacle to achieving it, its ability to build local authority through recognition is likely to be low, and local actors more likely to dissociate themselves from an ITA rather than seek its approval. Similarly, if local actors have alternative audiences that can provide them with similar benefits, for example because the international presence is divided and individual states will provide them with support, recognition from an ITA is unlikely to matter strongly.

\section{Strengthen the capacity of selected local actors and organisations to advance and justify authority claims}

Authority not only needs to be recognised, it also needs to be claimed, and the statebuilding efforts of ITAs are central to advancing the ability of particular local actors to make authority claims. While political authority can be claimed on a wide range of grounds in conflict affected states, including all three of Max Weber's ideal types of authority (charismatic, traditional, and legal-rational), ${ }^{50}$ international administrations have largely focussed on building legal-rational authority, rooted in formal rules governing the access to and exercise of political power. ${ }^{51}$ In addition to establishing the legal foundations for formal state institutions (e.g. through the drafting of constitutions, and electoral processes), the central focus of authority-building practices has been on strengthening the capacity of these institutions to deliver public services (in particular security), so that the state can fulfil its responsibilities under an implicit social contract and build authority vis-à-vis the population.

Such efforts to build state authority rest on a particular view of the state and its relationship to society that permeates the activities of ITAs: the state is seen as an actor autonomous from

\footnotetext{
${ }^{50}$ Max Weber. Economy and Society: An Outline of Interpretive Sociology (edited by Guenther Roth and Klaus Wittich) (Berkley: University of California Press 1978), 212-99.

${ }^{51}$ However, it is important to note that some recent statebuilding efforts have tried to fuse formal-legal with charismatic and traditional forms of authority. In East Timor, Xanana Gusmao's authority from early on under UNTAET arguably rested on his charismatic personality and his previous role as the leader of the resistance movement; while in Afghanistan, the use of the Loya Jirga, and of community-level Shuras (for example in Helmand) were efforts to fuse rational-legal authority with traditional elements.
} 
society, deriving its authority from an implicit social contract. Strengthening state capacity then not only improves its ability to fulfill its responsibilities under a social contract but also strengthens its infrastructural power and its autonomy from sectional interests, ${ }^{52}$ while the focus on accountability and democratic legitimacy aims to ensure that the state continues to act within the bounds of the social contract. "State-building", in the words of the OECD, therefore "involves the ongoing negotiation of an unwritten contract between state and society". ${ }^{53}$ Associated with this view of statebuilding is a particular understanding of the particular "authority problem" that such environment pose, which is rooted in the weakness, persistent fragility and even the collapse of state institutions. ${ }^{54}$ The lack of state capacity and with it the absence of state authority - is seen as the key challenge to be addressed by statebuilding, rather than the relationship between different social groups and the state, the competing authority claims that they make, and the role of state institutions in managing these competing claims. ${ }^{55}$

Recent writings on state failure and statebuilding have explicitly taken this latter dimension into account, ${ }^{56}$ and have recognised that it is often the character of the relationship between different groups (and the role of state institutions in shaping this relationship), and in particular relationships of exclusion and marginalisation, that have fuelled inter-communal conflict and civil war in places such as Burundi, Kosovo, Macedonia, Sierra Leone, or Sudan. ${ }^{57}$ This also has important implications for the understanding and evaluation of authority building practices of international transitional administrations.

\footnotetext{
${ }^{52}$ Michael Mann, "The autonomous power of the state: its origins, mechanisms, and results", European Journal of Sociology, Vol.25, No.2 (1984), pp.185-213

${ }^{53}$ OECD/DAC, Supporting Statebuilding in Situations of Conflict and Fragility, DAC Guidelines and Reference Series (Paris: OECD Publishing, 2011), p.13.

${ }^{54}$ See for example Ashraf Ghani, and Claire Lockhart, Fixing Failed States (New York: Oxford University Press, 2008); Jeffrey Herbst, , 'Responding to State Failure in Africa', International Security, 21/3 (1997), 12044, William Zartmann, (ed.), Collapsed States: The Disintegration and Restoration of Legitimate Authority, (Boulder, Co.: Lynne Rienner, 1995).

55 The literature on international administrations generally associates the governance mandate of ITAs with the need to managing competing authority claims, rather than their statebuilding mandate. See for example Joel C. Beauvais, 'Benevolent Despotism: A Critique of U.N. State-Building in East Timor', New York University Journal for International Law and Politics, 33/4 (2001), pp.1101-78; Wilde, International Territorial Administration.

${ }^{56}$ See for example Katia Papagianni, 'Participation and State Legitimation', in Charles Call and Vanessa Wyeth (eds.), Building States to Build Peace (Boulder, Co.: Lynne Rienner, 2008), 49-71; Dominik Zaum, "Statebuilding and Governance: The Conundrum of Local Legitimacy and Local Ownership", in Devon Curtis and Gwinyayi Dzinesa (eds.), Peacebuilding, Power, and Politics in Africa (Athens, OH: Ohio University Press, 2012), 47-62.

${ }^{57}$ Lars-Erik Cederman, Kristian Skrede Gleditsch, and Halvard Buhaug, Inequality, Grievances, and Civil War (Cambridge: Cambridge University Press, 2013); Mats Berdal and Dominik Zaum (eds.), Political Economy of Statebuilding : Power after Peace (Abingdon: Routledge, 2012).
} 
When the state is not autonomous from sectional interests, reforming formal state institutions and strengthening their capacity is not a neutral, technical exercise but deeply political: it selectively strengthens the capacity of those actors controlling state institutions to support and enforce their authority claims. The breadth of these activities, and the variation across cases makes is unwise to generalise about their impact in this regard, but it is possible to make some broader observations with regard to several key statebuilding activities, such as the drafting of constitutions, and the strengthening of public service delivery.

Constitutional reforms are common aspects of international state- and peacebuilding efforts, and in particular of international administrations. The Peace Accords Matrix, a database on peace accords since 1989, identifies 19 peace agreements with provisions for constitutional reform. ${ }^{58}$ In the post-cold war period, all international administrations of political units larger than a single city (such as the special administrations for the Bosnian cities of Mostar and Brčko) or that were tasked with the reintegration of a territory into a state (UNTAES in Croatia) engaged in constitutional reforms (four out of the seven post-cold war ITAs). The formal legislative and executive powers of international administrations have given them strong leverage over constitutional design processes, in particular through their agenda setting powers, their veto powers, their drafting powers, and their power to impose particular provisions bypassing local actors. ${ }^{59}$

However, as Oisin Tansey notes, despite these substantial formal powers, constitutional design processes tend to be strongly influenced by local political dynamics both during the drafting and the implementation of constitutional provisions. ${ }^{60}$ Constitutions are rarely imposed but negotiated with local actors who have substantial capacity for resistance and adoption, resulting in "hybrid" outcomes that reflect a mixture of both international and local elite priorities, ${ }^{61}$ which reflect a mixture of the "red lines" of international actors and the key priorities and interests of the most powerful local negotiators. These can be substantive (with regard to particular policy issues) or procedural (to entrench a particular power distribution). With regard to the former, one of the best examples comes not from an ITA but from the

\footnotetext{
${ }^{58}$ See https://peaceaccords.nd.edu. The database contains 34 peace agreements concluded between 1989 and 2012 (accessed 15 February 2016).

${ }^{59}$ Oisin Tansey, "Statebuilding and the Limits of Consitutional Design", in Mats Berdal and Dominik Zaum (eds.), Political Economy of Statebuilding: Power after Peace (Abingdon: Routledge, 2012), p.19.

${ }^{60}$ Ibid.

${ }^{61}$ Roger MacGinty, International Peacebuilding and Local Resistance: Hybrid Forms of Peace (Basingstoke: Palgrave Macmillan, 2011)
} 
related "transformative occupation" of Iraq following the 2003 US-led invasion, ${ }^{62}$ where Shiite negotiators managed to include into the Transitional Administrative Law a provision that forbade the passage of any law that contravened "the universally agreed tenants of Islam". ${ }^{63}$ With regard to the latter, in East Timor the Fretilin party used its majority in the constitutional assembly to push through a constitution based largely on its own earlier draft and that arguably aimed in part at consolidating its dominant position within the Timorese political landscape: it explicitly recognised Fretilin's contribution to the independence struggle, employed the national symbols (anthem and flag) devised in 1975 when Fretilin declared East Timor's independence, and most importantly provided for a relatively weak presidency (which Fretilin expected to be Xanana Gusmao) vis-à-vis the government and parliament (which it could reasonably expect to dominate). ${ }^{64}$ UNTAET's approval of the constitution-drafting process and support for the final document thus helped to entrench the existing political power structures.

The provision of public services is considered as central by donors to generating state legitimacy, and by extension state authority. ${ }^{65}$ While models of "performance" or "output" legitimacy are theoretically and politically appealing (as they chime with well-established theories of the state and provide relatively clear pointers for policy), empirical support for the importance of service delivery for perceptions of state authority and legitimacy is contested: as Claire McLoughlin points out, the relationship between service delivery and legitimacy is not linear, it is shaped by expectations from populations towards the state, and also by how public services are delivered. ${ }^{66}$ For the purpose of this discussion, however, it is important to

\footnotetext{
${ }^{62}$ See Steven R. Ratner, "Foreign Occupation and International Territorial Administration: The Challenges of Convergence" European Journal of International Law 16/4 (2005), 695-719; David Scheffer, "The UN Security Council and the International Law on Military Occupations", in Vaughan Lowe et al. (eds.), The UN Security Council and War: the Evolution of Thought and Practice since 1945 (Oxford: Oxofrd University Press, 2008), 580-607.

${ }^{63}$ Noah Feldman, What We Owe Iraq: War and the Ethics of Nation Building (Princeton: Princeton University Press, 2004), p.88

${ }^{64}$ Anthony Goldstone, "Building a state and 'statebuilding': East Timor and the UN, 1999 - 2012", in Mats Berdal and Dominik Zaum (eds.), Political Economy of Statebuilding Power after Peace (Abingdon: Routledge, 2012), pp.216-9. It is worth noting that while Fretilin dominated the early years of Timorese independence, he party was defeated in 2007, following the collapse of public order and a growing conflict between the government and the president in 2006.

${ }_{65}$ See for example DFID, Building Peaceful States and Societies; OECD/DAC, The State's Legitimacy in Fragile Situations.

${ }^{66}$ Claire McLoughlin, "When does Service Delivery Improve the Legitimacy of a Fragile or Conflict-Affected State?", Governance, forthcoming. The observation that processes, or how services are delivered, matters chimes with studies of the psychology of legitimacy from developed countries, which emphasise the importance of perceptions of fairness of processes. See for example Tom Tyler, "A Psychological Perspective on the Legitimacy of Institutions and Authorities", in John T. Jost and Brenda Major (eds.) The Psychology of Legitimacy: Emerging Perspectives on Ideology, Justice, and Intergroup Relations (Cambridge: Cambridge University Press, 2001), pp.416-36.
} 
highlight another issue: improving the provision of public services is not a neutral exercise, but strengthens the ability of particular groups (those that control the government) to make authority claims. While it might be that donors use their assistance to improve service delivery strategically to support particular actors; local elites themselves, who through joint planning and aid allocation processes can have some influence over where aid is targeted (either in particular sectors or geographically), can seek to use this assistance strategically to entrench their authority. In Kenya for example (though not an example of international administration, but a country with a strong international aid presence), Ryan Jablonski has shown that successive governments have consistently influenced aid allocation processes to direct assistance towards areas with many co-ethnic and co-partisan voters, to influence voting patterns and maximise the votes of the incumbent government. ${ }^{67}$

ITAs, and international donors more generally, not only support states and governments, but also civil society. While the bulk of assistance and focus has been on the former, building the authority of civil society and strengthening its capacity to influence and constrain state power, in particular through greater monitoring and transparency, and through advocacy, has been an important part of donors' portfolio. From 2002 until 2012, assistance from OECD/DAC donors for civil society and democratic participation in fragile states has grown from $\$ 123$ million to $\$ 600$ million worldwide. ${ }^{68}$ The role of civil society in peacebuilding has generated a large literature, which has, among other things, highlighted the problem of an "uncivil" civil society in conflict-affected states that is more likely to sustain than criticise exclusive and discriminatory structures of political authority. ${ }^{69}$ Such uncivil society represented in particular through veterans' organisations or martial arts clubs - has been an important feature of the political landscape of a range of countries with international administrations, including Bosnia, Kosovo, and East Timor. ${ }^{70}$ Even where civil society might conceivably pose a counterweight to state institutions and the groups controlling them, however, the practices of ITAs and donors more generally, tend to strengthen the position of the executive vis-a-vis actors that might control them, like civil society but also parliaments, in particular the tendency to work through governments, and rely heavily on closed door

\footnotetext{
${ }^{67}$ Ryan Jablonski, How aid targets votes: the impact of electoral incentives on foreign aid distribution. World Politics, 66/2 (2014), pp. 293-330.

${ }^{68} \mathrm{http}: / /$ www.oecd.org/development/stats/idsonline.htm.

${ }^{69}$ Roberto Belloni, "Civil society in war-to-democracy transitions", in Anna Jarstad and Timothy Sisk (eds.), From War to Democracy: Dilemmas of Peacebuilding (Cambridge: Cambridge University Press, 2008), pp.182210.

${ }^{70}$ Belloni, "Civil society in war-to-democracy transitions"; Goldstone, "Building a state and "statebuilding".
} 
negotiations. ${ }^{71}$ Also, even if funding for civil society support on fragile states has increased, it only makes up a small amount of the government and civil society support category of the OECD/DAC data - less than $10 \%$ in 2012, down from around $12 \%$ in 2002.

As with processes of claiming and recognising authority, capacity building efforts by international transitional administrations are shaped by the complex interactions between local elites and the international presence, which highlights the importance of paying attention to agency when examining practices of authority building. It also highlights that building authority is inherently political, and affects the question of who exercises power as much (or even more) as the questions of how and to what end it is exercised.

\section{Conclusion}

This paper examined the authority-building practices of international transitional administrations. Authority is normally conceived of in hierarchical terms, ascribing an entitlement to obedience to those actors in authority. As this paper suggests, in environments of international transitional administration, such a hierarchy might exist formally, reflected in particular in the strong mandates that many ITAs have been endowed with, but that in practice these relationships are far more complex and fluid. Similarly, ITA efforts of building political authority - both their own and that of local actors and institutions - are multifaceted, owing to the social nature of authority, and the need for it to be claimed as well as recognised. Four issues stand out in this regard.

First, environments with ITAs do not tend to suffer form an absence of authority (as much of the state failure literature suggests), but tend to suffer from multiple, and competing, authority claims. "Authority-building" is therefore not about creating authority, but rather about concentrating it, and formalising its exercise and justification. In all the cases discussed in this paper, ITAs did not create new authorities but strengthened and formalised the authority of actors that could already successfully claim it vis-à-vis selected audiences within the affected societies.

Second, and related, despite the soaring transformative rhetoric of their mandates, international authority-building efforts are strongly shaped by the realities on the ground: the existing structures of power that have emerged from or shaped by the previous armed conflict. ITAs, with their substantial resources (both material and ideational) have been able to shape the character of political authority in the affected societies, and who exercises it, but

\footnotetext{
${ }^{71}$ See Susan Woodward, "The IFIs and the post-conflict political economy", in Mats Berdal and Dominik Zaum (eds.), Political Economy of Statebuilding: Power after Peace (Abingdon: Routledge, 2012), p.151.
} 
have not been in a position to determine it, despite the comprehensive formal powers of the mandates of some ITAs.

Third, the discussion shows that local and international authority is closely intertwined in ITA contexts, and there are strong interdependencies between local and international actors and their authority claims. This interdependency is not only rooted in the character of the mandates of ITAs, and their inherently transitional nature, but more generally in the nature of political authority, in particular the importance of recognition by different audiences, both local and international.

Finally, a focus on authority and authority building in the context of the international administration of war-torn territories usefully shifts the focus of analysis to issues of agency. Examining the claiming and recognition of political authority in such environments highlights how power and authority do not just depend on the rules and institutions that govern access to political office, and to rents and resources; but importantly also on the actions of those actors asserting or challenging these rules - both local and international. The focus on agency helps to understand that the "hybrid" outcomes that have been observed widely across state- and peacebuilding contexts are not so much the consequences of failed policies by international actors, but rather a reflection of the inherently contested, and constantly negotiated character of authority in such environments. 